\title{
Does Training and Employee Commitment Predict Employee Retention?
}

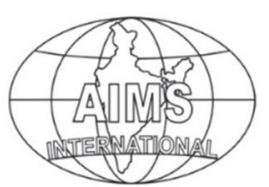

DOI: $10.26573 / 2018.12 .3 .1$

Volume 12, Number 3

September 2018, pp. 153-160

\author{
Nasreen Khan \\ SZABIST \\ (nasreen@szabist.ac.ae)
}

Employee retention is evidently linked with an organization's competitive advantage. A very limited attention is given to the predictors of employee retention in UAE. Training and employee commitment are directly and/or indirectly linked with employee retention. In this study how training and employee commitment predict employee intentions to stay has been examined. Data was collected from 124 employees working at different levels in private sector using convenience sampling method. Hierarchical regression analysis was conducted to assess the strength of predictors. Findings of the study have managerial implications across different industries.

\subsection{Brief Overview}

\section{Introduction}

Employee turnover is a hard pressing concern globally. It is neither industry specific nor region specific. Hence the significance of ways in which employee turnover issues can be most effectively addressed is immense. As per the reported findings by Bureau of National Affairs in 2016 employee turnover cost for businesses in USA was approximately $\$ 11$ billion per annum. From organization's perspective, hiring, training and retaining employees is a challenging and costly affair.

Organizations strive to find ways in which they will be able to retain their talent. Employee retention affects their overall branding efforts and sustainability in the market. Employee retention is a thorny issue for organizations around the world. Reduced turnover intentions are required to be achieved via strategic efforts by the decision makers, and by increasing job satisfaction and organizational commitment. With an increasing competitive labor market, demand for talent is at its peak, which in turn demands organizations to focus more upon retaining their talent.

As per the research findings by (Yazinski, 2009), employee retention is very challenging for most of the organizations. As per the findings reported by Yazinski, (2009), more than $50 \%$ of the organizations experience retention as an ongoing problem. In the same research (Yazinski, 2009) stated that $70 \%$ of the organizations find it difficult to fill in replacement candidates. Dube et al (2010) stated that the average cost of replacement is in the range of $\$ 3,000$ to $\$ 4,500$. Costs associated with employee turnover include visible costs and invisible costs. Recruitment costs, relocation, orientation and formal training costs are visible costs. Invisible costs include loss of productivity, loss of knowledge, low morale, loss of clients etc. (Hussein Alkahtani, 2015). 
These empirical study findings indicate how much importance employee retention has for organizations. As employee turnover intentions and employee retention are two sides of the same coin, it is critical to understand the reasons of employee turnover intentions in order to retain employees. The predictors of retention and turnover may not necessarily carry same effect. Employee retention is defined as "systematic effort by employers to create and foster an environment that encourages current employees to remain employed by having policies and practices in place that address their needs".

Employees have certain needs/expectations from their organizations, mainly, competitive compensation, growth opportunities, performance feedback, work life balance, organizational support, fairness and justice. Organizations must make sincere efforts to fulfill employee needs/expectations. Employers must examine the causes of employee turnover, and strategically address those causes in order to retain employees. Some of the most commonly investigated predictors of employee turnover are organizational commitment \& job satisfaction (Hussain \& Asif, 2012), financial rewards and benefits (Cappelli, 2001), training and development opportunities (Anderson et al, 2002), work environment (Allen et al, 2003), and work-life balance (Horwitz et al, 2003).

The consequences of employee turnover are poor employee productivity (Dube et al, 2010), knowledge loss (MIitchell \& Lee, 2001), and poor employee engagement (Bhattacharya, 2015). Employee retention is thus associated with increased profitability, higher productivity, better client relationship, employee commitment and loyalty etc... Highly committed employees have higher tendency to remain with their current organization. They feel more engaged, work harder and display a more positive attitude at work. An organization seeking to foster commitment approach/strategy would significantly decrease the likelihood of an employee to search for employment elsewhere. Likewise, training and development is positively associated to increased organizational commitment, while commitment is strongly and inversely related to turnover intention. Effective talent-centric strategy, finding, hiring, and developing the best people in line with the organizational strategy, needs to be the focus of organizations. In this paper both employee training and employee commitment are examined as predictors of employee retention. From these two, the construct which predicts turnover intentions effectively is examined.

\subsection{Predictors of Employee Retention}

Employee retention is important for an organization as finding right kind of talent is very difficult. In the current economic conditions many organizations are experiencing human resource challenges. Under such circumstances most commonly followed survival strategies of organizations is layoff. When organizations are terminating employment, employees prefer to leave voluntarily. Employee retention is measured by employee turnover and employee attrition. Employee retention refers to integrated efforts taken by organizations, on account of which employees develop a positive evaluation of organizations and may not voluntarily leave an organization. Training and development opportunities are significantly related to retention of employees. Allen et al (2003) have found that supervisory support, mainly via recognition and feedback of performance has an impact on employee retention. External and internal career opportunities influence affective commitment and employee intentions to leave. 
Organizational commitment refers to the psychological attachment of an employee to the organization. Mowday, Porter and Steers (1982), defined organizational commitment as "a strong belief in and acceptance of the organization's goals and values; a willingness to exert considerable effort on behalf of the organization; and a strong desire to maintain membership in the organization". Committed employees are better contributors to the organization's performance. Meyer and Allen (1991) proposed the three-component model of organizational commitment: affective commitment, continuance commitment and normative commitment. "Affective commitment refers to "the emotional attachment to, identification with, and involvement in the organization"; Continuance commitment is "an awareness of the cost associated with leaving the organization"; and Normative commitment reflects "a feeling of obligation to continue employment" (Meyer and Allen 1991).

Affective commitment is the strongest predictor of turnover. It is explained by the fact that employees value positive work experiences. An organization that provides employees with positive work experiences increases employees' desire to stay. In addition, the employee will be more likely to contribute to organizational effectiveness to maintain equity in their relationship with the organization, i.e., the norm of reciprocity applies. It is fostered by earlier researches showing the correlation between commitment and turnover. Employees who had a higher level of commitment also had a higher level of turnover cognitions. This means the employee had a more favorable attitude to stay and was less likely to consider turnover. This shows a negative relationship between organizational commitment and turnover intention. When the organizational commitment of an employee is high, turnover intention is low and when organizational commitment is low the turnover intention will be high.

Employee commitment, mainly affective and normative commitment, employee engagement and autonomy have been found to reduce employee intentions to leave. Higher commitment is helpful in minimizing the damages caused by employee turnover. Employee commitment and employee intentions to stay are positively related. Employee satisfaction and employee engagement are found to be affecting productivity, profitability, employee retention, safety and customer satisfaction. Meyer et al (2002) stated that employee commitment and absenteeism is negatively related to employee intentions to leave along with quitting, stress and work family conflict. Job satisfaction is the most evident retention factor.

Employee retention is directly linked with employee learning, and age has a significant effect on turnover intentions and employee retention. Job stress and job burnout are other important predictors of employee turnover intentions. Personal resources are positively affecting work engagement, which in turn negatively affects turnover intentions. Organizational commitment is found to be negatively related to turnover intentions. As per Curtis \& Wright (2001), organizational commitment is an important indicator of employee retention.

Training is "any attempt, within or outside the organization, to increase job related knowledge and skills of either managers or employees". Training\& development is a "planned intervention that is designed to enhance the determinants of individual job satisfaction". Training was supposed to be cost to the company, but the fact is investment in training and development is evidently ripping positive organizational benefits. Availability of training is related to organizational commitment, which turn is negatively related to turnover intentions Jehanzeb et al. (2013). Mentoring is found 
to be positively related to affective commitment and continuance commitment and negatively related to turnover intentions.

Training and development is linked to organizational commitment and the association is positive. Higher training opportunities result into higher levels of commitment. Organizations offering training to employees is perceived as a reward, and in turn employees show higher level of commitment and loyalty. It is empirically established that employee attitude towards training and training effectiveness is positively related to organizational commitment. Training provisions are positively related to employee retention and employee loyalty.

Those organizations who invest in employee training are more likely to experience better employee retention. Even though most of the literature supports the view that training is positively affecting employee retention, there are evidences which suggest otherwise. Loss of employees and shortage of key staff are reportedly the other effects of training. Regardless of where one falls within this debate, most professionals agree that training and development is a complex human resource practice that can significantly impact a company's success. Career development opportunities, is one of the top ranked predictors of employee retention. Training and development may benefit the organization but a much greater impact is made through various organizational commitment practices.

H1: Training predicts employee retention

H2: Employee commitment predicts employee retention

H3: Training predicts employee retention better than employee commitment

\section{Methodology}

Data was collected using simple random sampling method from 124 employees working in private sector organizations in Dubai. Most of the respondents (63\%) belong to the age group of 21 to 30years, $27 \%$ respondents were between the age group of 31 to 40 years, with remaining $10 \%$ of 41 years and above. $83 \%$ of them were graduates while $64 \%$ of the respondents were with above 5 years of work experience. In the research, the employee tenure was as follows: around $10 \%$ employees were working in the current organization for less than 1 year; $72 \%$ between 1 to 5 years; and 18\% of the respondents were working in the current organization for 5 years and above. When the respondents were asked about the frequency of trainings provided in the present organization, 54\% stated frequently, $32 \%$ sometimes and $14 \%$ very frequently.

Training was measured using a twenty eight item scale developed by Noe and Schmitt (1986) and Noe and Wilk (1993) which measures training and development effectiveness. Sample items of the scale were, 'My organization provides a good environment for new recruits to learn job-specific skills and knowledge', and 'My manager supports my participation in training and development programs'. The Cronbach's alpha value $(\alpha)$ for the scale was 0.84 . Organizational commitment was measured using the Organizational Commitment Questionnaire (OCQ) created by Meyer and Allen (1997) fifteen item scale. It consists of statements describing employees' attitudes and feelings towards their organization. Organizational commitment was measured by sample items 'I find that my values and the organization's values are very similar', and 'This organization really inspires the very best in me in the way I perform my job'. The Cronbach's alpha value $(\alpha)$ for the scale was 0.78. Employee retention was assessed using adopted eight item scale 
developed by Wang (2012). Sample items 'Enjoying my job' and 'I like the way my firm does the business and what it stands for'. The Cronbach's alpha value $(\alpha)$ for the scale was 0.87 .

\section{Results and Discussion}

To determine if training and employee commitment have an impact on employee retention, multiple hierarchical regression was conducted. The results are tabulated in Table 1. As shown in Table 1, model 1 refers to training predicting employee retention and model 2 refers to training and employee commitment predicting employee retention. Here in model 2 the R Square value went up by more than $13 \%$ once employee commitment was added in the regression. The R Square $(0.162$ or $16.2 \%)$ is significant at $\mathrm{F}(1,123)=16.785$, $\mathrm{p}<0.05$. Model 2 with two predictors showing improvement over model 1 with an $\mathrm{R}$ Square of $(0.294$ or $29.4 \%)$ is significant at $\mathrm{F}(1,121)=26.312, \mathrm{p}<0.05$. Table 2 provides ANOVA summary indicating that both model 1 and 2 are significant at $\mathrm{p}<0.05$.

Table 1 Model Summary

\begin{tabular}{|c|c|c|c|c|c|c|c|c|c|}
\hline \multirow{2}{*}{ Model } & \multirow{2}{*}{$\mathbf{R}$} & \multirow{2}{*}{$\begin{array}{c}\mathbf{R} \\
\text { Square }\end{array}$} & $\begin{array}{c}\text { Adjusted } \\
\mathbf{R} \\
\text { Square }\end{array}$ & \multirow{2}{*}{$\begin{array}{c}\text { Std. Error of } \\
\text { the Estimate }\end{array}$} & \multicolumn{4}{|c|}{ Change Statistics } \\
\cline { 6 - 9 } & & & & $\begin{array}{c}\text { R Square } \\
\text { Change }\end{array}$ & $\begin{array}{c}\text { F } \\
\text { Change }\end{array}$ & df1 & df2 & $\begin{array}{c}\text { Sig. F } \\
\text { Change }\end{array}$ \\
\hline 1 & $0.416^{\mathrm{a}}$ & 0.162 & 0.154 & 49.431 & 0.162 & 16.785 & 1 & 123 & .000 \\
\hline 2 & $0.632^{\mathrm{b}}$ & 0.294 & 0.279 & 45.612 & 0.134 & 26.312 & 1 & 121 & .000 \\
\hline
\end{tabular}

a. Predictors :( Constant), Training, Employee Retention

b. Predictors: (Constant), Training, Employee Commitment, Employee Retention

Table 2 ANOVA Summary

\begin{tabular}{|l|l|c|c|c|c|c|}
\hline \multicolumn{2}{|c|}{ Model } & Sum of Squares & df & Mean Square & F & Sig \\
\hline \multirow{2}{*}{1} & Regression & 1.5759696 & 1 & 1.5759696 & 33.46599 & $.000^{\mathrm{a}}$ \\
\cline { 2 - 7 } & Residual & 2.5900418 & 123 & 0.0470917 & & \\
\cline { 2 - 7 } & Total & 4.1660114 & 124 & & & \\
\hline \multirow{2}{*}{2} & Regression & 4.784073 & 1 & 4.784073 & 82.0195 & $.000^{\mathrm{b}}$ \\
\cline { 2 - 7 } & Residual & 2.438472 & 123 & 0.046894 & & \\
\cline { 2 - 7 } & Total & 7.222546 & 124 & & & \\
\hline
\end{tabular}

a. Predictors :( Constant), Training, Employee Retention

b. Predictors :( Constant), Training, Employee Commitment, Employee Retention

Table 3 Coefficients

\begin{tabular}{|l|l|c|c|c|c|c|}
\hline \multirow{2}{*}{\multicolumn{2}{|c|}{ Model }} & \multicolumn{2}{c|}{$\begin{array}{c}\text { Unstandardized } \\
\text { Coefficients }\end{array}$} & $\begin{array}{c}\text { Standardized } \\
\text { Coefficients }\end{array}$ & t & Sig. \\
\cline { 2 - 7 } & B & Std. Error & Beta & & \\
\hline \multirow{2}{*}{1} & (Constant) & 1.575 & 0.213 & & 6.054 & .000 \\
\cline { 2 - 8 } & Training & 2.590 & 0.058 & 0.416 & 10.665 & .000 \\
\hline \multirow{2}{*}{2} & (Constant) & 0.646 & 0.179 & & 3.603 & .000 \\
\cline { 2 - 8 } & Training & -0.243 & 0.069 & 0.282 & -3.53 & .000 \\
\cline { 2 - 8 } & Employee & 1.031 & 0.086 & 0.484 & 11.939 & .000 \\
\hline
\end{tabular}


Table 3 implies that all standardized coefficients (Beta values) are significant at $\mathrm{p}<0.05$. Employee commitment has higher Beta value $(\beta=.48, \mathrm{p}<0.05)$ as compared to training $(\beta=.28, \mathrm{p}<0.05)$. Thus making employee commitment a better predictor of employee retention in comparison to training. The hypotheses testing results are, $\mathrm{H} 1$ accepted as training predicts employee retention, $\mathrm{H} 2$ accepted as employee commitment predicts employee retention, and $\mathrm{H} 3$ rejected as employee commitment predicts employee retention better than training.

\section{Conclusion and Recommendations}

The study has explored if training and employee commitment predict employee retention. The data was collected from private sector organizations and the findings were analyzed by using hierarchical regression. Further it is investigated if training predicts employee retention better than employee commitment. As discussed earlier, employee retention is a key concern as it is directly linked to organization's growth, reputation and performance. Effective trainings may lead to employee retention. Similarly a committed workforce minimizes employee turnover intentions. Based on this interpretation, effective training and development programs can help to retain employees and build a more stable work force. When an employee feels a lack of commitment to its organization, it can tremendously affect the intention to leave or not. Previous studies showed that organizational commitment is the strongest predictor of turnover (Tett and Meyer, 1993). The findings of the study indicated that employee commitment is a better predictor of employee retention which finds support in similar findings by Miller, Rutherford, \& Kolodinsky (2008). Therefore, employee commitment is more significantly predicting employee retention. The findings of the study have organizational implications. The decision makers may focus more on ways to enhance commitment levels of the employees. Similarly identifying employee training needs and delivering effective trainings is another way of retaining employees. If the proper trainings are provided, then the employees can be retained effectively. When an employee remains with an organization for a long period of time they can lower down the turnover rate efficiently.

\section{References}

1. Allen et al. (2003), 'The role of perceived organizational support and supportive human resource practices in the turnover process' Journal of Management, 29(1), pages 99-118.

2. Ali Hussein Alkahtani, 'Investigating factors that influence employee's turnover intention: A review of existing empirical works, International Journal of Business and Management, 10(12), page 152. Anderson et al. (2002), 'Formal organizational initiatives and formal workplace practices: links to work-family conflict and job-related outcomes' Journal of Management, 28.

3. Bhattacharya, Y. (2015), 'Employee Engagement as a Predictor of Seafarer Retention: A Study among Indian Officers', The Asian Journal of Shipping and Logistics, 31(2), pages 295-318.

4. Cappelli, P. (2001). A market-driven approach to retaining talent. Harvard Business School Press, Boston, MA.

5. Cohen, A. (2003), 'Multiple commitments in the workplace: An integrative approach' Psychology Press. 
6. Dube et al. (2010), 'Employee replacement costs', UC Berkeley: Institute for Research on Labor and Employment. Retrieved from http://escholarship.org/uc/item/7kc29981

7. Jehanzeb, K., Rasheed, A., \& Rasheed, M. F. (2013), 'Organizational commitment and turnover intentions: Impact of employee's training in private sector of Saudi Arabia', International Journal of Business and Management, $8(8)$, pages 79 .

8. Horwitz et al. (2003), 'Finders, keepers? Attracting, motivating and retaining knowledge workers', Human Resource Management Journal, 13, pages 23-44.

9. Hussain \& Asif. (2012), 'Is employees' turnover intention driven by organizational commitment and perceived organizational support', Journal of quality and technology management, 28.

10. Meyer, J. and Allen, N. (1991). A three-component conceptualization of organizational commitment. Human Resource Management Review, 1(1), pp.61-89.

11. Meyer, J. and Allen, N. (1997). Commitment in the workplace. Thousand Oaks, Calif.: Sage Publications.

12. Miller, B. K., Rutherford, M. A., \& Kolodinsky, R. W. (2008). Perceptions of organizational politics: A meta-analysis of outcomes. Journal of Business and Psychology, 22(3), 209-222.

13. Mckeown, J. (2002), 'Retaining Top Employees', New York: McGraw-Hill.

14. MIitchell \& Lee. (2001), 'The unfolding model of voluntary turnover and job embeddedness', Research in Organizational Behavior, 23.

15. Noe, R. and Schmitt, N. (1986). The Influence of Trainee Attitudes on Training Effectiveness: Test of a Model. Personnel Psychology, 39(3), pp.497-523.

16. Noe, R. and Wilk, S. (1993). Investigation of the factors that influence employees' participation in development activities. Journal of Applied Psychology, 78(2), pp.291-302.

17. Sherwyn, D. a. (2002), 'Job-sharing in the hotel industry: a potential new human resource tool resulting from the events of September $11^{\text {th }}$, Cornell Hotel and Restaurant Administration, 43(5), pages 84-91.

18. Steers, R.M. (1977), 'Antecedents and outcomes of organizational commitment', Administrative Science Quarterly, 22(1), pages 46-56.

19. Tett, R. and Meyer, J. (2006). Job Satisfaction, Organizational Commitment, Turnover Intention, and Turnover: Path Analyses Based on Meta-Analytic Findings. Personnel Psychology, 46(2), pp.259-293.

20. Wang, Y.H. (2012), 'Recruitment and retention of knowledge workers in Taiwan's high technology industry', Doctoral dissertation. Cardiff University.

21. Yazinski, S. (2009), 'Strategies for Retaining Employees and Minimizing Turnover', Hr.blr.com.

\section{About Our Author}

Nasreen S. Khan Ph.D. is an Associate Professor at the Shaheed Zulfiqar Ali Bhutto Institute of Science and Technology, Dubai, UAE. She earned an MBA from Bharti Vidyapeeth, Kolhapur, Maharashtra, India, and her Ph.D. in Organizational Behavior from Banasthali Vidyapeeth, Jaipur, Rajasthan, India. Her current areas of research include organizational commitment, work family enrichment, constructive deviance, 
work family conflict, workplace stress, employee well being and turnover intentions. Her research has been published in journals such as European Journal of Scientific Research, British Journal of Marketing Studies, European Scientific Journal, and Asian Research Journal of Business Management. 